\title{
HEAVY METAL PROFILES IN VARIOUS MATRICES OF THE BONNY/NEW CALABAR RIVER ESTUARY, NIGER DELTA, NIGERIA
}

B. B. BABATUNDE, F. D. SIKOKI, M. C. ONOJAKE, R. U. AKPIRI AND D. AKPULOMA

\begin{abstract}
A study of the concentrations of $\mathrm{Ca}, \mathrm{Mg}, \mathrm{K}, \mathrm{Zn}, \mathrm{Pb}, \mathrm{Cd}, \mathrm{Co}, \mathrm{Cr}, \mathrm{Cu}, \mathrm{Fe}, \mathrm{Ni}$ and $\mathrm{Na}$ in the sediment, sea water, fish and crab of the Bonny/New Calabar River Estuary in Niger Delta, Nigeria was carried out using atomic absorption spectrophotometer A-100 for two consecutive years. The contamination levels of the respective metals varied between 2011 and 2012and the range of mean values for all metals in $\mathrm{mg} / \mathrm{kg}$ were presented along with variations at statistically significant level $(P<0.05)$ between the two years studied. Only $\mathrm{K}, \mathrm{Zn}$ and Co exhibited variation in their concentrations in water samples between the two years at a statistical significant level $(P<0.05)$ probability. In sediment, only $\mathrm{Cr}$ varied between the two years at a statistically significant level $(P=0.05)$. All metals concentrations were higher in sediment than in water samples.Bioaccumulation factor (BF) indicated a more potent source of metals from sediment than water with organisms accumulating $\mathrm{Zn}, \mathrm{Fe}$ and $\mathrm{Ni}$ in the magnitude of 10,6 and 5 times more from sediment than from water. Some metals were more accumulated in fish than crab and vice versa. The evidence of elevated levels of heavy metals in sediment and bioaccumulation in biota in the studied area may poise a wanton threat to the health of inhabitants whose diet is predominantly fish. This calls for regular monitoring to avert potential public health problems arising from consumption of metals in seafood.
\end{abstract}

KEYWORDS: Heavy metals, Matrices, bioaccumulation, Bonny River, Niger Delta, Nigeria.

\section{INTRODUCTION}

The Niger Delta accounts for over $90 \%$ of Nigeria's foreign exchange earnings through oil and gas export. However, it suffers extensive environmental pollution, such as heavy metal and hydrocarbon contamination as a consequence of oil and gas exploration and exploitation, industrial production and urbanization, which together have significantly impacted its ecological systems for many years (Akpomuvie, 2011). The Bonny estuary, location of the present study, is one of a network of creeks in the Niger Delta region that empties directly into the Atlantic Ocean at Bonny Island. It is tidal and thus receives a high influx of sea water most of the year (Dublin-Green, 1988). Large scale oil and gas production, industrialization and urbanization characterise the study location with reported impacts from oil spills, gas flares, industrial discharges,

B. B. Babatunde, Centre for Marine Pollution Monitoring and Seafood Safety, University of Port Harcourt, Port Harcourt, IAEA-FGN Project, RAF/7009.

F. D. Sikoki, Centre for Marine Pollution Monitoring and Seafood Safety, University of Port Harcourt, Port Harcourt, IAEA-FGN Project, RAF/7009.

M. C. Onojake, Centre for Marine Pollution Monitoring and Seafood Safety, University of Port Harcourt, Port Harcourt, IAEA-FGN Project, RAF/7009.

R. U. Akpiri, Centre for Marine Pollution Monitoring and Seafood Safety, University of Port Harcourt, Port Harcourt, IAEA-FGN Project, RAF/7009.

D. Akpuloma, Centre for Marine Pollution Monitoring and Seafood Safety, University of Port Harcourt, Port Harcourt, IAEA-FGN Project, RAF/7009. 
agricultural runoff and domestic effluents and leachates (Jamabo and Chinda, 2010). The estuary also supports marine transportation by heavy vessels conveying goods and services to and from a petroleum tank farm, Port Harcourt wharf, cement and flour factories, among others, in addition to heavy traffic of fast speed boats for communal transportation.

Despite these activities, artisanal fisheries in the estuary largely support the livelihood of its inhabitants who have little or no knowledge of the extent of contamination in the estuary. Fish remains an important part in the diet of Nigerians, especially for riverine communities such as the inhabitants of the study area, with seafood being served at almost every meal. In Nigeria, especially in rural and fishing communities, fish constitute approximately $75 \%$ of animal protein consumed (Edun et al., 2010). Fish is consumed either freshly prepared or smoked. Shellfish, especially the Tympanotonusspecies, are used largely as a condiment in most meals eaten in the Niger Delta (Gomna and Rana, 2007).

In Africa and developing world where environmental protection laws have sparingly been enforced, industrial and domestic wastes containing toxic and hazardous substances including heavy metals are dumped indiscriminately into water bodieswhich eventually settle in bottom sediments (Oguzie 2002). According to Bineyet al.(1994), microbial and redox processes may change the properties of sediments and affect the composition of interstitial water, while reworking of the sediments by organisms will also bring sediments to the surface, where a significant fraction of heavy metals will be released. A good knowledge of the distribution of heavy metals in water and sediments plays a key role in detecting the sources of pollution in aquatic systems (IdodoUmeh and Oronsaye 2006). Bottom sediments are particularly useful to monitor heavy metal pollution in aquatic ecosystems because they serve as a sink for archiving contaminants.

Several workers have investigated the concentration of heavy metals in the coastal rivers with Atlantic tidal effect in Nigeria.A good account of such studies in the Niger Delta is given in the work of Asonye et al. (2007) in which heavy metal load of several rivers in Nigeria were reported.Generally, heavy metal concentration have been reported to be low in Nigerian water bodies by earlier workers, notable among which are Obireet al. (2003) on Elechi Creek, Chindahet al. (2004) on lower Bonny River, Omoigberale and Ogbeibu (2005) on Ase River, Southern Nigeria. The use of fish and invertebrates as bioindicators of water quality has also been advocated by some workers (Yamazaki et al.1996). This is because they produce evidence of relatively stable concentration compared with water analysis that indicates only short term conditions. Fufeyin(1998) investigated trend of heavy metal concentrations in Lagos Lagoon ecosystem, Nigeria, and reportedthat the concentration of the metals detected in the lagoon sediments, water and animal samples collected from zones of the lagoon that received most of the industrial effluents, generally had higher concentration than samples collected from zones which received fewer or no industrial effluents. Davies et al.(2006) in the studies on heavy metal load in water and sediment and bioaccumulation of heavy metals in periwinkle (Tympanotonusfuscatusvar. radula) from Elechi Creek, Niger Delta, reported that the sediment concentrated more heavy metals than the water, while periwinkles accumulated more of these metals than found in its environment.

Bonny/New Calabar River Estuary system is vital to the people of Niger delta and other surrounding regions. It is perhaps one of the largest arms of the River Niger discharging directly into the Atlantic Ocean.and it is believed to also be the most environmentally stressed (Dublin-Green 1994).Artisanal fishery is a common sustenance to inhabitants on its banks. Several independent researchers have reported at different times the heavy metal load in this Estuary (Chindahet al. 2004; Davies et al.2006; Obireet al. 2003). However, there has been no coordinated approach to monitor heavy metal levels in the estuary, hence the present study aim to determine the levels of heavy metal pollution in the sediment, sea water, fish and crab of Bonny Estuary to establish changes over a period of two years and evaluate bioaccumulation patterns of metals in biota as part of an ongoing monitoring exercise along Nigeria's coastline for integrated catchment management supported by international funding agencies.

\section{MATERIALS AND METHODS Study Area}

The study area stretched from lower reach of Bonny River at Bonny town by Peterside community to Choba town in the upper reach of the New Calabar River. The entire stretch from the Bonny to Choba is largely influenced by the 
tidal cycles, about $20 \mathrm{~km}$, lies between longitude $7^{\circ} 00^{\prime \prime}$ to $7^{\circ} 15^{\prime \prime} \mathrm{E}$ and latitude $4^{\circ} 25^{\prime \prime}$ to $4^{\circ} 45^{\prime \prime} \mathrm{N}$. The tidal amplitude is generally high and above $2 \mathrm{~m}$ at the Bonny terminaljetty. However, the water level increases and decreasesdepending on the lunar cycle. At high tides, salinity increases and decreases at low tides. Sea influence is experienced more at high tide regime than at low tide, when the effect decreases especially within the upper limits when fresh water input dominates the zone.

The fan-shaped Niger Delta, which is the third largest in the world after the Mississippi (USA) and Pantanal (South-West Brazil), lies between latitudes $\left(4^{\circ}\right.$ and $\left.6^{\circ}\right)$ north of the equator and longitudes $\left(5^{\circ}\right.$ and $\left.9^{\circ}\right)$ east of the Greenwich Meridian. The predominant coastal vegetation of the Bonny River due to its tidal influence is the mangrove, whose main species are the red and white mangroves which form more than nineteen percent $(19 \%)$ of the saline swamps (Nwilo and Badejo, 2008). The white mangroves occur scattered among the red mangroves and thrive in less water-logged places. The Bonny river system is characterized by the interaction of an estuarine and highly saline seawater located seaward of the river mouth (typical of the Niger Delta coastal region), and influenced by tide- and wind-driven surface currents. The coastal areas of Bonny River play host to many fishing settlements while the river itself is a major navigational channel for oil vessels, countless outboard engine boats, maritime and oil-related activities.

\section{Sampling and sample preparations}

Grab bottom sediment samples were collected quarterly over a two year period (2011-2012) using and kept in plastic containers which had previously been treated with $10 \%$ nitric acid for 24 hours and rinsed with de-ionized water. The samples were transported to the Laboratory and stored frozen. The samples were later oven-dried to constant weight at $105^{\circ} \mathrm{C}$, ground to powder and then sieved through a $650 \mu \mathrm{m}$ stainless sieve to remove ungrounded matter. 10grams of the sieved sediments was weighed into an acid- washed plastic polythene bottle and digested in a $100 \mathrm{ml}$ solution of conc. $\mathrm{HNO}_{3}$ and $\mathrm{HCl}$ acids (1:1 ratio). The mixture was vigorously shaken in a mechanical shaker and then filtered through No 42 Whatchman filter paper (Idodo-Umeh and Oronsaye, 2006). All acid used were of analytical grade quality and control was assured by the use of procedural blanks and spikes. The spike recovery for each element was greater than $94 \%$. All samples were run in triplicates and the relative standard deviation for the triplicate analysis was less than $10 \%$. Standard solutions of the metals were prepared from their $1000 \mathrm{ppm}$ stock solutions for calibration

\section{Sample analysis}

The concentrations of the metals ( $\mathrm{Ca}, \mathrm{Mg}, \mathrm{K}, \mathrm{Zn}$, $\mathrm{Pb}, \mathrm{Cd}, \mathrm{Co}, \mathrm{Cr}, \mathrm{Cu}, \mathrm{Fe}, \mathrm{Ni}$ and $\mathrm{Na}$ ) were determined using a Varian Atomic Absorption Spectrophotometer (Perkin Elmer Analyst AA 200 equipped with a high sensitivity nebulizer). A one way analysis of variance was performed to compare the difference in concentration between the two years for sediment and water samples. Metal concentrations in crab and fish were compared using multiple bar charts.

Bioaccumulation factor (BF) was calculated to determine the level of heavy metal accumulation in the tissue of the organism using the formula below,

$\mathrm{BF}=\frac{\text { Concentration of metals in seafood }(\mathrm{mg} / \mathrm{kg})}{\text { Concentration of metals in water } / \mathrm{sediment}(\mathrm{mg} / \mathrm{kg})}$ Where:

BF is the ratio of metals concentration in seafood tissues to the concentration in wateror sediment calculated using Microsoft Excel package 2010.

\section{Results and Discussions.}

Results of trace metals analysis in water, sediments, Fish and Crab from the Bonny/New Calabar River Estuary system are presented in Table 1 and Figs. 1-3. The range values and the test of statistical significance between heavy concentrations of the two years of sampling are presented in Table 1 and bioaccumulation factors in Table 2. 
Table 1: Range values and $P$ values of heavy metal concentrations in water and sediment from the Bonny/New Calabar Estuary system for 2011/2012

\begin{tabular}{lllllll}
\hline Metal & Water & \multicolumn{5}{c}{ Sediment } \\
\hline & $\mathbf{2 0 1 1}$ & $\mathbf{2 0 1 2}$ & P values & $\mathbf{2 0 1 1}$ & $\mathbf{2 0 1 2}$ & P values \\
$\mathrm{Ca}$ & $4.8-10.8$ & $3.1-10.6$ & 0.178 & $3.1-10.5$ & $7.5-10.9$ & 0.530 \\
$\mathrm{Mg}$ & $51.4-52.7$ & $50.2-57.1$ & 0.421 & $50.6-53.3$ & $52.2-53.4$ & 0.199 \\
$\mathrm{~K}$ & $20.7-30.3$ & $19.8-38.1$ & $0.011^{*}$ & $18.7-28.3$ & $18.3-57.1$ & 0.199 \\
$\mathrm{Zn}$ & $0.1-0.6$ & $0.1-2.5$ & $0.002^{*}$ & $1.5-3.3$ & $0.2-6.0$ & 0.303 \\
$\mathrm{~Pb}$ & $0.2-0.3$ & $0.2-0.3$ & 0.702 & $0.2-0.6$ & $0.2-0.9$ & 0.131 \\
$\mathrm{Cd}$ & $0.09-0.1$ & $0.02-0.2$ & 0.628 & $0.0-0.1$ & $0.01-0.3$ & 0.430 \\
$\mathrm{Co}$ & $0.2-0.4$ & $0.4-0.6$ & $0.027^{*}$ & $0.4-0.7$ & $0.3-0.7$ & 0.470 \\
$\mathrm{Cr}$ & $1.1-1.9$ & $0.1-2.9$ & 0.111 & $0.8-1.8$ & $1.0-3.8$ & $0.005^{*}$ \\
$\mathrm{Cu}$ & $0.4-0.5$ & $0.3-1.2$ & 0.642 & $1.4-1.9$ & $0.4-2.2$ & 0.343 \\
$\mathrm{Fe}$ & $0.4-4.5$ & $0.3-1.3$ & 0.170 & $0.4-38.0$ & $0.6-38.7$ & 0.822 \\
$\mathrm{Ni}$ & $0.1-0.4$ & $0.1-0.3$ & 0.396 & $0.2-0.7$ & $0.2-0.8$ & 0.912 \\
$\mathrm{Na}$ & $0.6-6.7$ & $3.1-5.1$ & 0.633 & $4.1-23.3$ & $5.1-18.7$ & 0.916 \\
\hline
\end{tabular}

Table 2: Concentration factors of metals in fish and crab with reference to water and sediment.

\begin{tabular}{lllllllllllll}
\hline \multicolumn{10}{c}{ CF = Concentration factor } \\
\hline Medium & $\mathbf{C a}$ & $\mathbf{M g}$ & $\mathbf{K}$ & $\mathbf{Z n}$ & $\mathbf{P b}$ & $\mathbf{C d}$ & $\mathbf{C o}$ & $\mathbf{C r}$ & $\mathbf{C u}$ & $\mathbf{F e}$ & $\mathbf{N i}$ & $\mathbf{N a}$ \\
\hline CF fish/water & 0.19 & 0.98 & 0.73 & 0.94 & 0.90 & 0.09 & 1.50 & 1.48 & 0.11 & 0.08 & 1.14 & 0.34 \\
CF crab/water & 0.17 & 0.94 & 0.82 & 0.21 & 1.17 & 1.06 & 1.15 & 0.70 & 1.06 & 0.53 & 3.13 & 0.64 \\
CF fish/sediment & 0.25 & 0.99 & 0.78 & 10.08 & 2.12 & 0.14 & 2.53 & 1.66 & 0.23 & 1.02 & 1.96 & 1.22 \\
CF crab/sediment & 0.21 & 0.95 & 0.87 & 2.25 & 2.76 & 1.64 & 1.94 & 0.79 & 2.28 & 6.85 & 5.40 & 2.28 \\
\hline
\end{tabular}




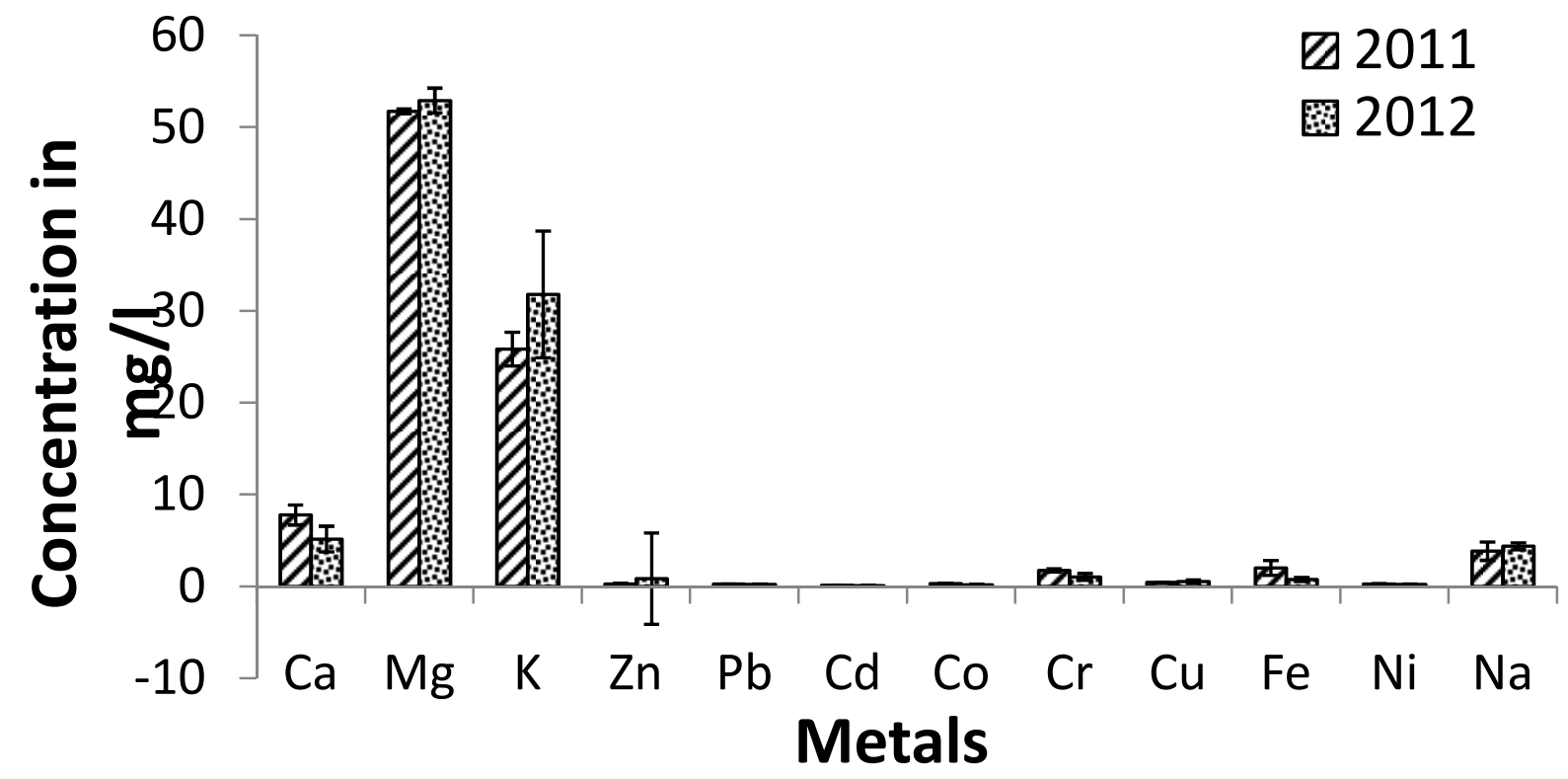

Fig. 1: Mean heavy metal concentration in water from the Bonny/New Calabar River Estuary system (n $=5)$.

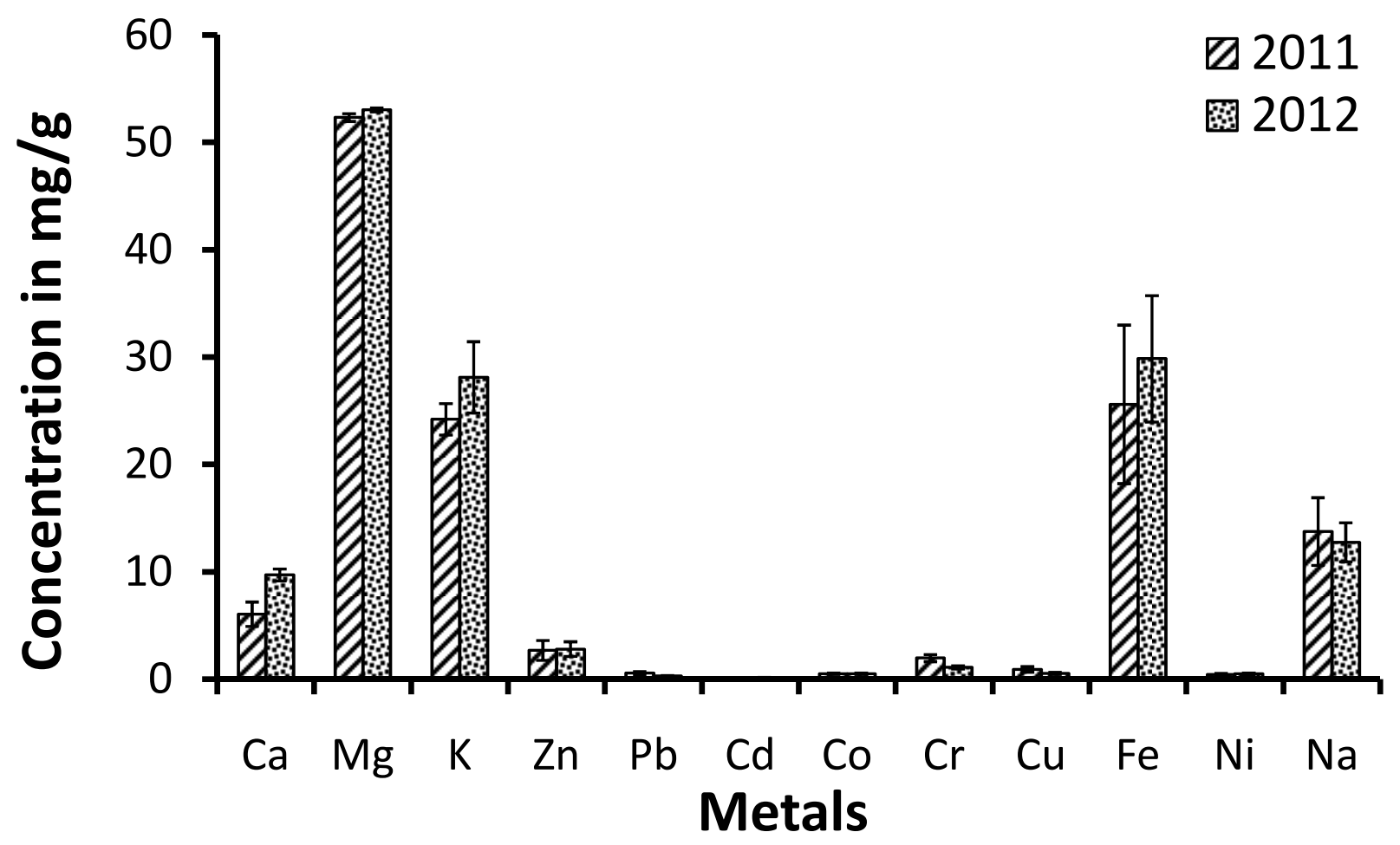

Fig. 2: Mean heavy metal concentration in sediment from the Bonny/New Calabar River Estuary system $(n=6)$. 


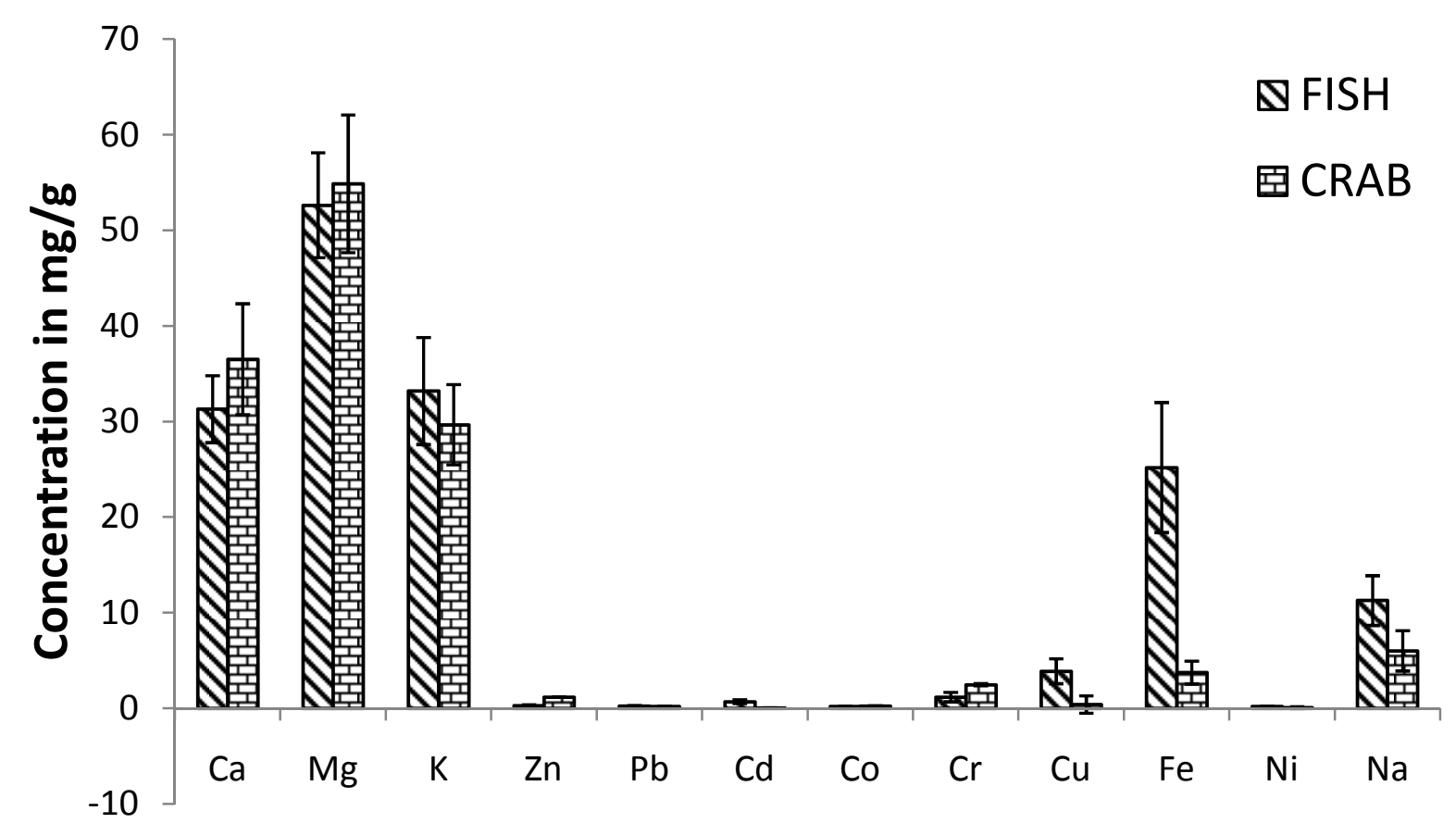

\section{Metals}

Fig. 3: Mean heavy metal concentration in fish and crab from the Bonny/New Calabar River Estuary system $(n=3)$.

\section{Water}

Calcium concentrations in water ranged from 4.8-10.8 mg/L in 2011 and 3.1-10.6 mg/L in 2012 with 2011 recording a higher average value of $7.8 \pm 1.1 \mathrm{mg} / \mathrm{L}$ than $2012(5.2 \pm 1.4 \mathrm{mg} / \mathrm{L})$ but the difference was not statistically insignificant at $(P$ $>0.05)$ and the values were well within stipulated limits of $5-500 \mathrm{mg} / \mathrm{L}$ by US EPA (2004) and WHO, (2006). Concentrations of $\mathrm{Mg}, \mathrm{K}, \mathrm{Fe}, \mathrm{Ni}$ and $\mathrm{Na}$ were slightly higher in 2011 than 2012 but none recorded statistical significant variation value at $\mathrm{P}>0.05$ probability level between concentrations of the two years. Magnesium concentrations ranged from $51.4-52.7 \mathrm{mg} / \mathrm{L}$ in 2011 and $50.2-57.1 \mathrm{mg} / \mathrm{L}$ in 2012 with average values of $51.7 \pm 0.3$ and $52.9 \pm 1.4$ in 2011 and 2012 respectively and its concentrations did not vary significantly between the two years $(P=$ 0.4211 ). The concentrations of $K$ ranged from 20.7-30.3 mg/L in 2011 and $19.8-57.1 \mathrm{mg} / \mathrm{L}$ in 2012 with mean values of $25.8 \pm 1.8$ and $31.8 \pm 1.9$ $\mathrm{mg} / \mathrm{L}$ in 2011 and 2012 respectively. The concentration of $\mathrm{K}$ vary between the two years at a statistical significant level of $P<0.05(P=$ 0.0112 ) indicating increase in 2012. Zinc concentrations recorded a wider range in 2012 $(0.1-2.5 \mathrm{mg} / \mathrm{L}$ than $2011(0.1-0.6 \mathrm{mg} / \mathrm{L})$ at a statistical significant level $(P=0.002441)$. The statistical significance at $(P<0.05)$ indicated an increase in 2012 which was not as a result of chance but possible anthropogenic input. Mean valuesrecorded for $\mathrm{Zn}$ were $0.8 \pm 0.2$ and $0.3 \pm 0.1$ in 2011 and 2012 respectively. Furthermore, Zn values recorded in water samples during the two years showed levels higher than stipulated limits of $0.001 \mathrm{mg} / \mathrm{L}$ for drinkable water by WHO (2006).Elevated levels of $\mathrm{Zn}$ have been shown to adversely affect growth, survival, and reproduction animals (Eisler 1993).

The concentration of $\mathrm{Pb}$ was higher than stipulated limits of $0.01 \mathrm{mg} / \mathrm{L}$ for safe drinkable water by WHO, (2006) ranging from $0.2-0.3 \mathrm{mg} / \mathrm{L}$ in both 2011 and 2012 with statistical insignificant variation at $P>0.05$ probability level. Adverse effects caused by $\mathrm{Pb}$ to aquatic organisms include loss of sodium, reduced capability, and 
developmental problems and distorted algal growth (Freda 1991).Cadmium concentrations ranged from $0.09-0.1 \mathrm{mg} / \mathrm{L}$ in 2011 and $0.02-0.2$ $\mathrm{mg} / \mathrm{L}$ in 2012 with mean values of $0.1 \pm 0.001 \mathrm{mg} / \mathrm{L}$ and $0.1 \pm 0.003 \mathrm{mg} / \mathrm{L}$ in 2011 and 2012 respectively. Its concentration did not vary between the two years at a statistically significant level $(P=0.6281)$. However, $C d$ values were higher than $0.003 \mathrm{mg} / \mathrm{L}$ stipulated by WHO (2006) as a safe limit in drinkable water. Cadmium is an important factor in aquatic monitoring studies, because it has been found to be toxic to fish and other aquatic organisms. It is one of the most toxic elements with widespread carcinogenic effects in humans, widely distributed in the aquatic environment and bioaccumulates at all trophic levels, accumulating in the livers and kidneys of fish (Sindayaigaya, et al. 1994). Cobalt concentrations ranged from 0.2-0.4 in 2011 and 0.4-0.6 in 2012. Its concentration varied between the two years at a statistical significant level $(P$ $=0.0270$ ) with 2012 recording higher mean values of $0.5 \pm 0.04 \mathrm{mg} / \mathrm{L}$ than $0.3 \pm 0.003$ in 2011 . Chromium values were higher in 2012 than 2011 and higher than stipulated limit of $(0.05 \mathrm{mg} / \mathrm{L})$ by $\mathrm{WHO}$ (2006). Its concentrations ranged from 1.1$1.9 \mathrm{mg} / \mathrm{L}$ in 2011 and $0.1-3.8 \mathrm{mg} / \mathrm{L}$ in 2012 with mean values of $1.8 \pm 0.2$ and $2.1 \pm 0.6 \mathrm{mg} / \mathrm{L}$ in 2011 and 2012 respectively. Chromium in its hexavalent form has been known as a carcinogen and implicated in many health effects in animals (WHO 2006). Copper concentrations ranged from 0.4-0.5 in 2011 and 0.3-1.2 in 2012 with mean values of $0.4 \pm 0.02$ and $0.5 \pm 0.2$ in 2011 and 2012 respectively. All copper values were below permissible limits of $2 \mathrm{mg} / \mathrm{L}$ by WHO (2006) and US EPA (2004) and its concentrations did not vary at a statistical significant level between the two years studied $(P=0.6420)$.

The concentration of $\mathrm{Fe}$ was higher in 2011 than 2012 but not at a statistically significant level. It ranged from $0.4-4.5 \mathrm{mg} / \mathrm{L}$ in 2011 and $0.3-1.3 \mathrm{mg} / \mathrm{L}$ in 2012 with mean values of $2.0 \pm 0.8$ and $0.8 \pm 0.2 \mathrm{mg} / \mathrm{L}$. Nikel concentrations ranged from $0.1-0.4 \mathrm{mg} / \mathrm{L}$ in 20111 and 0.1-0.3 mg/L in 2012 with mean values of $0.3 \pm 0.04$ and $0.2 \pm 0.01$ in 2011 and 2012 respectively. Mean concentration of $\mathrm{Ni}$ was only slightly higher in $2012(P=0.3960)$. Sodium concentrations recorded ranged values from 0.6$6.7 \mathrm{mg} / \mathrm{L}$ in 2011 and 3.1-5.1 in 2012 and mean values of 3.81 .0 and $4.40 .4 \mathrm{mg} / \mathrm{L}$ in 2011 and 2012 respectively. Although the results of surface water concentrations of heavy metals observed in the present study agrees with the general opinion of low level heavy metal concentrations in surface water in the study area and Niger Delta (Abu and Egenonu2008; Asonye et al. 2007; Chindah et al. 2004; Ubalua et al. 2007), some of the toxic metals such as $\mathrm{Pb}, \mathrm{Cd}, \mathrm{Zn}, \mathrm{Ni}$ and $\mathrm{Cr}$ were higher than stipulated limits by WHO, (2006) and require continuous monitoring to detect malicious increases as a result of anthropogenic input and avert possible public health implications of these metals on consumers of water and seafood from the study area.

\section{Sediment}

The concentrations of all the metals measured in sediment apart from $\mathrm{Co}$ and $\mathrm{Na}$, were slightly higher in 2012 than 2011. However, only $\mathrm{Cr}$ recorded significant variation in its concentration between the two years Table 1 . Calcium ranged from $3.1-10.5 \mathrm{mg} / \mathrm{kg}$ in 2011 and $7.5-10.9 \mathrm{mg} / \mathrm{kg}$ in 2012 with mean values of $6.1 \pm 1.1$ and $9.7 \pm 0.6 \mathrm{mg} / \mathrm{L}$ in 2011 and 2012 respectively.Magnesium concentrations ranged from $50.6-53.3 \mathrm{mg} / \mathrm{kg}$ in 2011 and 52.2-53.4 $\mathrm{mg} / \mathrm{kg}$ in 2012 with mean values of $52.3 \pm 0.4$ and $53.0 \pm 0.1 \mathrm{mg} / \mathrm{kg}$ in 2011 and 2012 respectively. Potassium ranged from $18.7-28.3 \mathrm{mg} / \mathrm{kg}$ in 2011 and $18.3-38.1 \mathrm{mg} / \mathrm{kg}$ in 2012 with mean values of $24.2 \pm 1.5$ and $28.1 \pm 3.3 \mathrm{mg} / \mathrm{kg}$ in 2011 and 2012 respectively. Zinc ranged from 1.5-3.3 in 2011 and $0.2-6.0$ in 2012 with mean values of $2.7 \pm 0.9$ and $2.8 \pm 0.7 \mathrm{mg} / \mathrm{kg}$ in 2011 and 2011 respectively. Lead concentrations ranged from $0.2-0.6 \mathrm{mg} / \mathrm{kg}$ in 2011 and $0.2-0.9 \mathrm{mg} / \mathrm{kg}$ in 2012 with mean values of $0.6 \pm 0.1$ and $0.3 \pm 0.06 \mathrm{mg} / \mathrm{kg}$ in 2011 and 2012 respectively. Cadmium ranged from below detection limit to $0.1 \mathrm{mg} / \mathrm{kg}$ in 2011 and $0.01-0.2 \mathrm{mg} / \mathrm{kg}$ in 2012 with mean values of $0.06 \pm 0.02$ and $0.1 \pm 0.03 \mathrm{mg} / \mathrm{kg}$ in 2011 and 2012 respectively.

The concentrations of Co ranged from $0.4-0.7 \mathrm{mg} / \mathrm{kg}$ in 2011 and $0.3-0.4 \mathrm{mg} / \mathrm{kg}$ in 2012 with mean values of $0.5 \pm 0.05 \mathrm{mg} / \mathrm{kg}$ and $0.5 \pm 0.06 \mathrm{mg} / \mathrm{kg}$ in 2011 and 2012 respectively. Chromium ranged from $0.8-1.8 \mathrm{mg} / \mathrm{kg}$ in 2011 and $1.0-2.9 \mathrm{mg} / \mathrm{kg}$ in 2012 with mean values of $1.1 \pm 0.2 \mathrm{mg} / \mathrm{kg}$ and $2.0 \pm 0.3 \mathrm{mg} / \mathrm{kg}$ in 2011 and 2012 respectively. The concentrations of $\mathrm{Cu}$ and $\mathrm{Fe}$ in 2011 and 2012 ranged from 1.4-1.9 and $0.4-2.2 \mathrm{mg} / \mathrm{kg}, \quad 0.4-38.0$ and $0.6-38.7 \mathrm{mg} / \mathrm{kg}$ respectively with mean values of $0.9 \pm 0.3$ and $0.5 \pm 0.09 \mathrm{mg} / \mathrm{kg}, 25.6 \pm 7.4$ and $29.9 \pm 5.9 \mathrm{mg} / \mathrm{kg}$ for $\mathrm{Cu}$ and $\mathrm{Fe}$ in 2011 and 2012 respectively while that of $\mathrm{Ni}$ and $\mathrm{Na}$ ranged from $0.2-0.7$ and $0.2-0.8$ $\mathrm{mg} / \mathrm{kg}, 4.1-23.3$ and $5.1-18.7 \mathrm{mg} / \mathrm{kg}$ respectively with mean values of $0.4 \pm 0.09$ and $0.5 \pm 0.08$ 
$\mathrm{mg} / \mathrm{kg}, 13.8 \pm 3.2$ and $12.8 \pm 1.8 \mathrm{mg} / \mathrm{kg}$ for $\mathrm{Ni}$ and $\mathrm{Na}$ in 2011 and 2012 respectively.

Sediments are described as sink for contaminants. In the present study, all metals concentrations were higher in sediments than in surface water, however, only $\mathrm{Zn}, \mathrm{Fe}$ and $\mathrm{Na}$ recorded higher concentrations in sediment than surface water at statistically significant level $(P=$ $0.00351)$. Some studies have reported similar results for metals studied in the present research to range higher in sediment than surface water in the Bonny/New Calabar Estuary system and Niger Delta (Chindah et al. 2004, 2009). However, the general results obtained in this study for heavy metal concentrations in sediments were higher than that of other studies in the Niger Delta (Davies et al. 2006; Horsfall and Spiff 2002; Iwegbue et al. 2007; Obire et al. 2003).

\section{Fish and Crab}

Results of the analyses of heavy metals in fish and crab showed variability in the concentrations of the metals in the two animals Fig. 3. The concentration of $\mathrm{Ca}, \mathrm{Mg}, \mathrm{Zn}$ and $\mathrm{Cr}$ recorded higher values in crab than in fish. However, the differences in the concentrations of these metals in the two organisms was not statistically significant at $P>0.05$ probability level $(P=0.2612)$. The concentrations of $\mathrm{K}, \mathrm{Cd}, \mathrm{Pb}$, $\mathrm{Ni}, \mathrm{Cu}, \mathrm{Fe}$ and $\mathrm{Na}$ were higher in fish than in crab. However, only the concentrations of $\mathrm{Fe}$ and $\mathrm{Na}$ were higher at statistically significant level $(P$ $=0.01128$ ). Mean values of heavy metal concentrations in fish and crab are presented in Fig. 3. Fish samples showed $\mathrm{Mg}$ to record the highest concentration, followed by $\mathrm{Ca}$ and $\mathrm{K}$ while Co recorded the least mean concentration Fig. 3. In crab also, $\mathrm{Mg}$ recorded the highest followed by $\mathrm{K}, \mathrm{Ca}$ and $\mathrm{Fe}$ while $\mathrm{Ni}$ recorded the least mean concentration Fig. 3. All metals except $\mathrm{Ni}$ in crab recorded mean values higher than reported elsewhere in the Niger Delta (Agbozu et al., 2007; Chindah et al. 2009; Davies et al. 2006; Obire et al. 2003;Ubalua et al. 2007; Uyimadu et al. 2008,) and higher than stipulated limits for safe consumption of seafood by WHO (2006).

Seafoods have been recognized as good accumulators of organic and inorganic pollutants which are finally transferred to other animals including humans through the food chain. Bioaccumulation of metals showed different patterns in fish and crabstudied Table 2. The order of magnitude of accumulation of metals in fish from water was

$\mathrm{Co}>\mathrm{Cr}>\mathrm{Ni}>\mathrm{Mg}>\mathrm{Zn}>\mathrm{Pb}>\mathrm{K}>\mathrm{Na}>\mathrm{Ca}>\mathrm{Cu}>\mathrm{Cd}>\mathrm{Fe}$ and in crab the accumulation of metals was in the order of magnitude $\mathrm{Ni}>\mathrm{Pb}>\mathrm{Co}>\mathrm{Cd}>\mathrm{Cu}>\mathrm{Mg}>\mathrm{K}>\mathrm{Cr}>\mathrm{Na}>\mathrm{Fe}>\mathrm{Zn}>\mathrm{Ca}$.

Some of the metals such as $\mathrm{Ni}, \mathrm{Na}, \mathrm{Fe}, \mathrm{Cu}, \mathrm{Cd}$, $\mathrm{Pb}$ and $\mathrm{K}$ were better accumulated in crab with three times more $\mathrm{Ni}$ in crab than in fish.However, some of the metals such as $\mathrm{Cr}$, Co and $\mathrm{Zn}$ were better bioaccumulated in fish than in crab.Bioaccumulation of metals was generally higher in both organisms when sediment was the medium of evaluation with metals such as $\mathrm{Zn}$, Fe and $\mathrm{Ni}$ bioaccumulating in the magnitude of 10, 6 and 5 times higher in the organisms. This may be as a result of higher metal concentrations in sediment and the biology of the organisms studied which typifies bottom feeders. The order of magnitude of metal accumulation in fish from sediment was in the sequence $\mathrm{Zn}>\mathrm{Co}>\mathrm{Pb}>\mathrm{Ni}>\mathrm{Cr}>\mathrm{Na}>\mathrm{Fe}>\mathrm{Mg}>\mathrm{K}>\mathrm{Ca}>\mathrm{Cu}>\mathrm{Cd}$ while the pattern in crab was $\mathrm{Fe}>\mathrm{Ni}>\mathrm{Pb}>\mathrm{Na}>\mathrm{Cu}>\mathrm{Zn}>\mathrm{Co}>\mathrm{Cd}>\mathrm{Mg}>\mathrm{K}>\mathrm{Cr}>\mathrm{Ca}$.

The bioaccumulation patterns observed in the present study shows that even in similar media, different organisms may bioaccumulate contaminants differently and there may be specific factors influencing selective bioaccumulation of metals in the organisms which is beyond the scope of the present study. However, according to Eneji et al. (2011), the rate of bioaccumulation of heavy metals in aquatic organisms depends on the ability of the organisms to digest the metals and the concentration of such metal in the river. Also it has to do with the concentration of the heavy metal in the surrounding soil sediments as well as the feeding habits of the organism. Furthermore, some of the factors may include, age of fish, lipid content in the tissue and mode of feeding are significant factors that affect the accumulation of heavy metals in fishes. Similar studies have reported similar bioaccumulation patterns of metals in different organisms in the Bonny/New Calabar River Estuary (Chindah et al. 2009; Davies et al. 2006) and elsewhere in the Niger Delta (Olowoyo 2011) and River Benue (Eneji et al. 2011).

Heavy metals have multiple effects in biological systems depending on the oxidation state, the formation of complexes and biotransformation of elemental species. Health effects of heavy metals such as $\mathrm{Pb}, \mathrm{Zn}, \mathrm{Cr}, \mathrm{Cd}$ and $\mathrm{Cu}$ in humans have been demonstrated in acute toxicity, neurotoxicity and nephrotoxicity 
(Katz and Salem 1993; ATSDR 200; Stift et al. 2000; WHO 2011) while $\mathrm{Pb}$ is a confirmed carcinogen (Martin and Griswold 2009; WHO 2011).Some observed effects of $\mathrm{Ni}$ in aquatic environments include tissue damage, genotoxicity and growth reduction. Mollusks and crustaceans are more sensitive than other organisms (Onojake and Frank 2012).

\section{CONCLUSIONS}

Heavy metals from different sources are prevalent in coastal areas of the Bonny River, South-eastern Niger Delta. The present study showed that sedimentary heavy metals, surface water heavy metals, heavy metals in crab and fish in stations from the study area were of mixed biogenic, anthropogenic and industrial sources. Heavy metal concentrations showed slight increase over 24 months of monitoring in water and sediment samples with statistical significance in the variation of some of them at $(P<0.05)$ probability. The higher concentrations of heavy metals in sediment showed reiterated the general believe that sediment are a sink and archive for contaminants.

In all, crab and fish had the tendency to bio-accumulate metals with preferences for some depending source (water or sediment) in which $\mathrm{Zn}, \mathrm{Fe}$ and $\mathrm{Ni}$ bioaccumulated at magnitude of 10, 6 and 5 times higher in organisms from sediment than water. Bioaccumulation of metals in edible organisms is a threat to human health since the metals will be ultimately transferred to humans along the food chain with possibilities of increase concentration of tissue burden which may become fatal. Continuous monitoring to detect dangerous increases is therefore advocated.

\section{ACKNOWLEDGEMENT}

The authors wish to acknowledge the support of the International Foundation for Science (IFS) Stockholm, Sweden, through a grant to Babatunde B B(W/5246-1) and International Atomic Energy Agency (IAEA) through a Technical Cooperation (RAF7/008 \&009).

\section{REFERENCES}

Agbozu, I. E., Ekweozor, I. K. E and Opuene, K., 2007. Survey of heavy metals in the catfish Synodontisclarias. International Journalof Environmental Science and Technology 4, (1): 93-7.
Akpomuvie, O. B., 2011. Tragedy of commons: Analysis of oil spillage, gas flaring and sustainable development of the Niger Delta of Nigeria. Journal of Sustainable Development. 4, 200-10.

Asonye, C. C., Okolie, N. P., Okenwa, E. E and Iwuanyanwu, U. G., 2007. Somephysicochemical characteristics and heavy metal profiles of Nigerian rivers, streams and waterways. African Journal of Biotechnology. 6, (5): 617-624.

ATSDR., 2000. Toxicological profile for chromium. Atlanta, Georgia, United States Department of Health and Human Services, Public Health Service, Agency for Toxic Substances and Disease Registry.

Biney, C. A., Amuzu, A. T., Calamari, D., Kaba, N., Mbome, I. L., Neave, H., Chumba, P. B. O., Osibanjo, O., Radegonde, R and MAH.Saad., 1994. Review of heavy metals in the African aquatic environment. Ecotoxicology and Environmental Safety. (28): 134-159.

Chindah, A. C., Braide, A. S and Sibeudu, O. C., 2004. Distribution of hydrocarbons and heavy metals in sediment and a crustacean (Penaeusnotialis) from the Bonny River/New Calabar River Estuary, Niger Delta. African Journal Environmental Assessment and Management. (9): 1-17.

Chindah, A. C., Braide, S. A., Amakiri, J and Chikwendu, S. O. N., 2009. Heavy Metal Concnetrations in Sediment and Periwinkle -Tympanotonusfuscastusin the Different Ecological Zones of Bonny River System, Niger Delta, Nigeria. Open Journal of Environmental. Pollution and Toxicology.1, 93-106.

Davies, O. A., Allison, M. E and Uyi, H. S., 2006. Bioaccumulation of heavy metals in water, sedimentand periwinkle (Tympanotonusfuscatusvar radula)from the Elechi Creek, Niger Delta. Afri.J. of Biotech. (5): 968-973

Dublin-Green, C. O., 1988. Some textural characteristics and organic content of recent sediments in the Bonny estuary, Niger Delta. Technical Paper 67. 
Nigerian Institute of Oceanography and Marine Research, Lagos.

Edema, C. U., 1993. Heavy metals in shell fishes of Warri River catchment's area. Ph. D. Thesis, University of Benin, Benin City, Nigeria.

Eisler, R., 1993. Zinc hazards to fish, wildlife, and invertebrates: a synoptic review. U.S. Fish Wildl. Serv. Biol. Rep.10.

Eneji, Ishaq S., Rufus ShaAto and Annune, P. A., 2011. Bioaccumulation of Heavy Metals in Fish (Tilapia Zilliand ClariasGariepinus) Organs from River Benue, North. Central Nigeria. Pak. J. Anal. Environ. Chem. Vol. 12, No. 1 \& 2 25-31

Freda, J., 1991. The effects of aluminum and other metals on amphibians. Environmental Pollution, 71, 305-328.

Fufeyin, P. T., 1998. Heavy metal levels in some dominant fish of Ikpoba Reservoir, Edo State, Nigeria. Environmental Review, (2): 61-69.

Gideon O. Abu and ChidiebereEgenonu., 2008. The current pollution status of the new Calabar river in the Niger Delta region of Southern Nigeria: A survey of antibiogram profiles of its bacterial isolates.Afri.J.Environ. Sci. and Technol. 2, (6): pp. 134-141.

Gomna, A and Rana, K., 2007. Inter-household and intra-household patterns of fish and meat consumption in fishing communities in two states in Nigeria. Br. J. Nutr. 97, 145-152.

Horne, M. T and Dunson, W. A., 1995. Effects of low $\mathrm{pH}$, metals, and water hardness on larval amphibians. Arch. Environtal. Conta.Toxicol. (29): 500-505.

Horsfall, M and Spiff, A. I., 2002. Distribution and partitioning of trace metals in sediments of the lower reaches of the New Calabar River, Port Harcourt, Nigeria. Envi.Mgt and Ass. (78): 309-326

Idodo-Umeh, G and Oronsaye, J. A. O., 2006. Heavy metal pollution of the sediments from Eriora River in Olomoro town, Niger Delta, Nigeria. Journ.of Sustain. Trop. Agric. Res. (21): 74-81.

Iwegbue C. M. A, Nwajeige and Arimoro, F. O., 2007. Assessment of contamination by heavy metals in sediments of Ase River, Niger Delta, Nigeria. Res. J. Environ. Sci. (1): 220-228.

Jamabo, $\mathrm{N}$ and Chinda, A., 2010. Aspects of the ecology of Tympanotonus fuscatus var fuscatus (Linnaeus, 1758) in the mangrove swamps of the upper Bonny River, Niger Delta, Nigeria. Curr. Res. J. Biol Sci. 2, 42-47.

Katz, S. A and Salem, H., 1993. The toxicology of chromium with respect to its chemical speciation: A review. J. of Appl. Toxico. (13): 217-224.

Nwilo, P. C and Badejo, O. T., 2008. Impacts and management of oil spill in Nigerian coastal environment. Proceedings of the International Conference on the Nigerian State, Oil Industry and the Niger Delta. 1217-1232.

Obasohan, E. E., 2008. Heavy metals in the Sediment of Ibiekuma Stream in Ekpoma, Edo State, Nigeria. Afri. J. Gen. Agric. 4, (2):

Obire, O., Tamuno, D. C and Wemedo, S. A., 2003. Physicochemical quality of Elechi Creek in Port Harcourt, Nigeria. J. Appl. Sci. Environ. Mgt. (7): 43-49.

Oguzie, F A., 2002. Heavy metals in the sediments of the Lower Ikpoba River, Benin City, Nigeria. Sri Lanka J. Aqua. Sci. (7): 35-44.

Olowoyo, D. N., 2011. Heavy metal concentrations in periwinkle (Litorina L ittorea) and tilapia (Tilapia Zilli) from the coastal water of Warri, Nigeria.Am. J. Food. Nutr, 1, (3): 102-108.

Oluwande, P. A., Sridhar, M. K. C., Bammeke, A. $\mathrm{O}$ and Okubadejo, A. O., 1983. Pollution levels in some Nigerian Rivers. Water Res., 17, (9): 957-963. 
Omoigberale, M. O and Ogbeibu, A. E., 2005. Assessing the Environmental impacts of oil exploration and production on the Osse River, Southern Nigeria: 1. Heavy metals.Afri. J. of Environ. Poll.and Health, 4, (1): 27-32.

Onojake, M. C and Frank, O., 2012. Assessment of heavy metals in a soil contaminated by oil spill: A case study in Nigeria, Chemistry and Ecology, DOI:10.1080/02757540.2012.717619

Sindayigaya, E., RV. Cauwnbergh, H. Robberecht, and Deelstra, H., 1994. Copper, zinc, manganese, iron, lead, cadmium, mercury, and arsenic in fish from Lake Tanganyika, Burundi. Sci. Total Environ. (144): 103-115.

Ubalua, A. O., Chijioke, U., Cand, O. U., Ezeronye., 2007. Determination and assessment of heavy metal content in fish and shellfish in Aba River, Abia state, Nigeria KMITL Sci. Tech. J. 7, (1): 31-45.

Unyimadu, J. P, Nubi, O. A., Udochu, $U$ and Renner, K. O., 2008. Safety of Fish From Nigerian Coastal Waters used as biomarker for heavy metals and hydrocarbon contaminations for the Cross River, Nigeria. The Environmentalist.; (24): 29-3.

WHO., 2006. Guidelines for drinking-water quality (electronic resource). Incorporating first addendum - 3rd ed. Volume 1.Recommendations. World Health Organization, Geneva.

Yamazaki, M., Tanizaki, $\mathrm{Y}$ and Shimkawa, T., 1996. Silver and other trace elements in freshwater fish CarasiusauratusLangsodorfill, from Asakawa River, in Tokyo, Japan. Environmental Pollution, 94, (1): 83-90. 